\title{
THE BURNING OF FUELWOOD IN SOUTH AFRICA: WHEN IS IT SUSTAINABLE?
}

\author{
G.P. VON MALTITZ and R.J. SCHOLES
}

Forestek, CSIR, P.O. Box 395, Pretoria 0001, South Africa

\begin{abstract}
Fuelwood harvesting is considered sustainable when consumption is equal to or less than production. An empirical model was developed to estimate potential fuelwood production from savannas. The model is based on the observation that in semiarid savannas, biomass production is linearly dependent on rainfall. Woody basal area is linked to mean annual precipitation, and aboveground woody biomass is proportional to basal area. Production averages $4 \%$ of standing woody biomass and is corrected to exclude stems that are too small for harvesting. The model assumes that the entire area consists of seminatural savanna. Corrections for the land lost as a result of land transformation and degradation would have to be included. Data on land loss can most effectively be obtained from satellite imagery, with appropriate ground calibration. The model is based on limited data sets but in most instances has been validated against independently collected data. The model yields a reasonable prediction at a national and regional level, but estimates for limited areas or specific points on the ground may differ substantially from the predicted values. Model results indicate a potential for sustainable fuelwood production at the national level, but specific regions are using fuelwood at nonsustainable levels.
\end{abstract}

\section{Introduction}

The Intergovernmental Panel on Climate Change (IPCC) emissions inventory methods consider unsustainable use of fuelwood to be a source of net carbon dioxide $\left(\mathrm{CO}_{2}\right)$ emissions (UNEP et al., 1995). Completion of the inventory, therefore, requires an estimation of the amount of fuelwood that is used unsustainably, which in turn requires a consideration of both consumption and production patterns.

The burning of fuelwood is still the primary source of energy for most of sub-Sahara Africa (Anderson, 1986) - the majority of the rural population, even in relatively developed countries such as South Africa, still use wood as their primary energy source. Numerous studies indicate that in developing countries, wood is being consumed at nonsustainable levels (Bajracharya, 1983; Allen, 1985; Shackelton, 1994; Kaul, 1993; Kanetkar and Kaul 1994). Within South Africa, it is estimated that approximately 11 million metric tons of fuelwood is consumed annually (Gander, 1994). However, in South Africa there are no data based on detailed empirical studies to use in estimating the size of the sustainable fuelwood resources in the extensive woodland areas of the country.

Accurate estimates of fuelwood consumption are difficult because of methodological constraints and unreliable population demographics data. A number of estimates, largely based on questionnaires but with a few based on actual measurement, have been conducted within South Africa (summarized in Gander, 1994). Annual consumption rates vary greatly, from less than $250 \mathrm{~kg}$ per capita (Eberhard and Dickson, 1987) to more than $1100 \mathrm{~kg}$ per 
capita (Best, 1979) in rural areas and from $26 \mathrm{~kg}$ per capita to more than $742 \mathrm{~kg}$ per capita in semirural/periurban areas (Eberhard, 1986). Workers on commercial farms are also often dependent on fuelwood-the few available studies estimate 800 to $900 \mathrm{~kg}$ per capita (Gander, 1992). Gander (1994) estimates total fuelwood consumption for South Africa to be 11.3 million megagrams $(\mathrm{Mg})$, with the bulk, 6.6 million $\mathrm{Mg}$, consumed in the exBantustans and an additional 3.5 million $\mathrm{Mg}$ consumed by farm workers. Wood consumption rates depend on numerous issues such as wood availability, cost and availability of alternative fuels, levels of poverty, and the severity of the need for space heating. Not all fuelwood consumed is from the savanna regions. Forest patches, small woodlots, and wattle groves (Acacia spp.) are important wood sources, particularly in the grassland biome. Waste from commercial forestry also contributes to fuelwood availability but is probably of relatively limited importance at present (Gander, 1994).

The estimation of savanna primary production is based on the observation that in semiarid savannas, the relationship between biomass production and rainfall is linear (Scholes, 1990, 1993). Although the assumption of linearity is robust, site-specific circumstances are such that the relationship between biomass production and rainfall for any particular site is in some ways unique. For instance, the depth, texture, and nutrient status of the soil affect both the slope and intercept of the relationship. Factors such as temperature and light also influence primary production because they influence the physiological processes of the savanna vegetation. The generalized relationships developed in the following sections are based on a large number of sites encompassing a wide range of variation. For any particular site, the prediction of biomass is likely to be erroneous, but for regional averages involving many sites, the central tendency is both robust and sufficiently accurate for the purpose of broad survey.

The objective of this paper is to present a simple method for estimating sustainable biomass production on a regional scale, and to discuss the suitability of using this data as a basis for estimating $\mathrm{CO}_{2}$ emissions from unsustainable fuelwood burning.

\section{Method}

Mean annual precipitation was chosen as a suitable independent variable for nationwide predictive models, because it is available for all of Africa at a $30 \times 30 \mathrm{~m}$ resolution and for South Africa at a $1 \times 1 \mathrm{~m}$ resolution from the Computer Centre for Water Research (CCWR). Temperature data at a similar resolution are not currently available for the country, although they are being developed. Soil data are extremely difficult to use in national predictive models because of the spatial variability in soil properties at the local scale, the unavailability of a national digital database of soil properties, and a lack of understanding about the ways in which different soil properties affect tree growth.

Very few studies have investigated either total aboveground tree biomass or tree production rates within the savannas of southern Africa. It is, therefore, not possible to develop a direct relationship between either of these two parameters and mean annual 
precipitation. The following four-step approach was used to predict woody production potentials:

In step 1, a linear relationship was developed between the basal area of woody vegetation $\left(B A: \mathrm{m}^{2} / \mathrm{ha}\right)$ and the mean annual precipitation in South African savannas (MAP: $\mathrm{mm}$ ). Forty-three sample quadrats from fourteen sites spread throughout the savanna region of South Africa were used to develop this relation, and twenty plots from an independent study were used to validate it. Study sites were located in areas of seminatural savanna, and sample quadrats were located at a range of catenal positions. Basal area was calculated as the summation of the individual tree-stem area derived from stem-diameter measurements. Although there was a large degree of variance within the data, a significant correlation between basal area and rainfall was established $\left(\mathrm{r}^{2}=0.29, \mathrm{p}<0.05\right)$. The regression equation derived $(B A=-0.03535+0.0158 M A P)$ was very similar to a regression derived by Frost, of the Department of Biological Sciences, University of Zimbabwe, from a totally independent data set collected in Central Africa. The linear model based on South African data begins to deviate from Frost's exponential model only when rainfall values are greater than $1200 \mathrm{~mm}$ (see Figure 1). These rainfall values are greater than the expected rainfall in almost all South African savannas. Maximum basal area was limited to $32 \mathrm{~m}^{2} / \mathrm{ha}$, which represents the upper limit of the data.

In step 2, the aboveground woody biomass (WB:t/ha) was related to stand basal area. A linear regression model linking woody basal area to aboveground woody biomass was derived from Southern African data sources (Moore et al., 1967; Scholes, 1988; Rutherford, 1982; Endean, 1967; Dayton, 1978). Although only seven data points were available, a highly significant regression equation $(W B=-2.930+2.7 B A)$ was fitted $\left(r^{2}=0.93, p<\right.$ 0.001). This equation compares favorably to Frost's exponential model derived for basal area values less than $10 \mathrm{~m}^{2} / \mathrm{ha}$. At higher values, the linear model gives more conservative results. Maximum aboveground biomass was limited to values less than 144 t/ha based on data from Malaisse and Strand (1973).

In step, 3, the annual basal area increment was related to the stand basal area. Very few data sets exist for this purpose (Rutherford, 1984; Lubke and Thatcher, 1983; Rutherford and Kelly, 1978; van Vegten, 1984; Malaisse et al., 1975; Endean, 1967). The values range from $2.1 \%$ to $9.4 \%$, with a mode around $4 \%$ (Scholes and Walker, 1993). These data are often unreliable because of the complexities involved in measuring stem increment, and because the data were often collected over too short a span of years to adequately represent the fluctuations in rainfall. There appears to be a trend from higher values $(6 \%)$ at sites with low basal area, to low values $(2 \%)$ at sites with high basal area, but this trend is not statistically significant. The modal value used was $4 \%$, which corresponds to the rainfall range in South African sites, if indeed this relationship exists. This value represents the weakest point in the procedure, and could be in error by $\pm 50 \%$ because of the range in published values.

In step 4, a correction was made for that fraction of the aboveground biomass that is not considered useful as fuel. The lower size limit for fuel is an arbitrary decision, because 


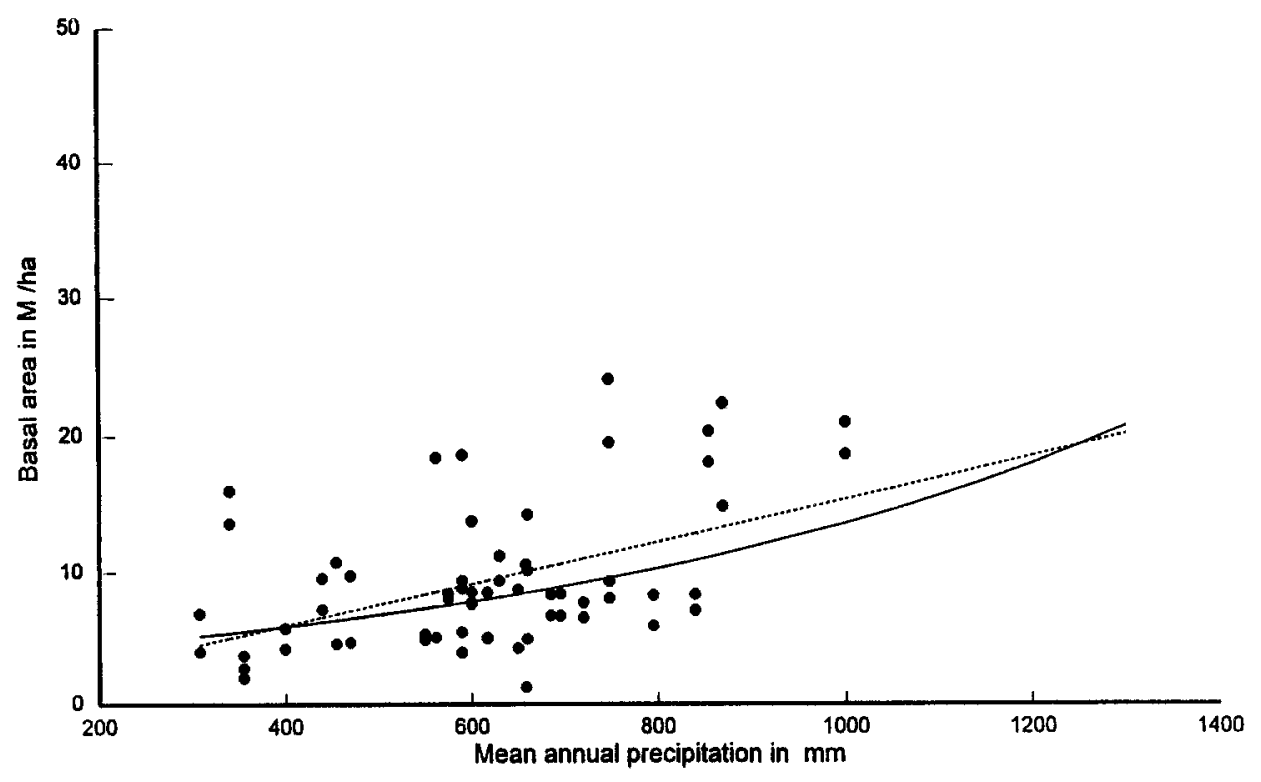

- DBH data

... Linear regression - Frost's equation

Figure 1. DBH (diameter at breast height) data from sixty-two sample plots showing the fitted regression equation and Frost's exponential model derived from independent data.

it varies with the use pressure. Output indicates that the model is not very sensitive to the influence of rainfall on the correction factor. A value of $0.025 \mathrm{~m}$ for the twig diameter $(T D: \mathrm{m})$ was used. The approach is based on the "pipe theory" for tree architecture, which predicts that the total cross-sectional area of a tree is relatively constant from the base to the twigs. Guy (1981) presents an equation that relates stem diameter to wood mass for individual savanna stems. The relationship appears stable over the entire data range. The wood biomass for the whole stem is, therefore, calculated by applying the equation to the mean stem $(M S D: m)$ diameter at the site $(W B=W B(1.0-\exp (\log (T D / M S D) 0.5101))$. The mass of an equivalent cross-sectional area, made up of $25 \mathrm{~mm}$ diameter twigs, is then subtracted.

The mean stem diameter at a site is derived from the observation that savannas across a broad rainfall range tend to have 500 to 1000 (averaging 800) stems per hectare that are greater than $50 \mathrm{~mm}$ in diameter. Substitution of the Guy relation into the predicted biomass per tree allows the mean stem diameter to be estimated as (MSD $=0.1807$ $\exp (0.00019604 M A P))$. It is a weak increasing function of rainfall. The result of these calculations reduces the predicted total woody biomass by $22.5 \%$ to $25 \%$ to yield a usable woody biomass estimate.

The data are applicable only to savanna areas. A digitized and rasterized vegetation map (Acocks, 1988) was used to determine the extent of the savanna biome in South Africa. 
The classification criteria of Rutherford and Westfall (1986), with modifications suggested by Ellery (1992), were used to reclassify the map to represent biomes. Data analysis was conducted with the CCWR rainfall data, a rasterized map of the Bantustans, and a derived biome map as input. The calculations were made with custom code written in the BASIC programming language on a microcomputer, and the resulting output was generated with IDRISI software. Results were computed at the national level, and for each ex-Bantustan for comparison against published consumption levels.

\section{Results}

A map of the predicted wood production in South African savannas is shown in Figure 2. The predicted total annual production of usable fuelwood from savannas in South Africa is 20 million $\mathrm{Mg}$, assuming no land-use transformation or land degradation. This estimate is based on a predicted total standing woody biomass of 762 million $\mathrm{Mg}$.

Table I shows the model's predictions of potential wood production from the savanna regions of the Bantustans. This is compared to published estimates of consumption per Bantustan.

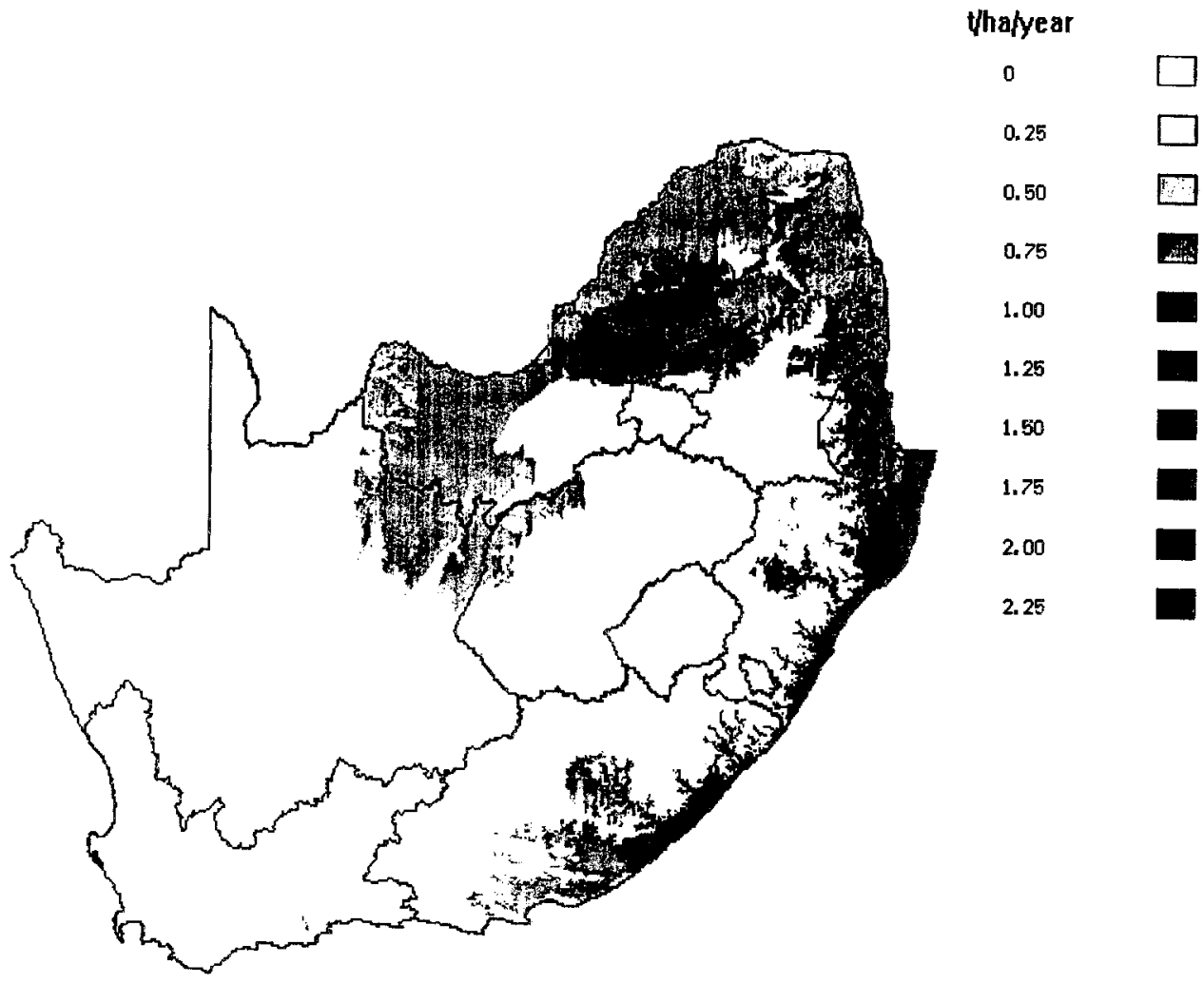

Figure 2. Potential biomass production of South African savannas in $\mathrm{Mg}$ ha yr. 


\section{TABLE I}

Predicted fuelwood consumption rates versus potentis production in the ex-Bantustan areas.

\begin{tabular}{lccrr}
\hline \% Savanna & $\begin{array}{c}\text { Annual } \\
\text { Consumption } \\
(000 \mathrm{Mg})^{*}\end{array}$ & $\begin{array}{c}\text { Factored } \\
\text { Consumption } \\
(000 \mathrm{Mg})\end{array}$ & $\begin{array}{r}\text { Potential } \\
\text { Savanna } \\
\text { Production } \\
(000 \mathrm{Mg})\end{array}$ \\
\hline Bophuthatswana & 93.5 & 483 & 451 & 1494 \\
Ciskei & 69.7 & 193 & 135 & 310 \\
Gazankulu & 99.9 & 452 & 452 & 362 \\
KaNgwane & 73.3 & 283 & 72 & 165 \\
KwaNdebele & 91.7 & 98 & 90 & 359 \\
KwaZulu & 63.9 & 2193 & 1401 & 1652 \\
Lebowa & 85.5 & 1271 & 1086 & 970 \\
QwaQwa & 0 & 26 & 0 & 0 \\
Transkei & 24.6 & 1311 & 322 & 1070 \\
Venda & 75.7 & 315 & 238 & 249 \\
\hline
\end{tabular}

* From Gander, 1994

Note: Consumption has been factored by the percentage of the area under savanna. This is a conservative estimate because fuelwood is likely to be transported out of the savanna areas, and consumption is likely to be highest in the savanna areas where fuelwood is more easily obtainable.

\section{Discussion}

The predicted sustainable wood production rates presume the existence of healthy savanna vegetation over the entire savanna region. Land transformation or degradation has, however, accrued over most of the savanna region. Analysis of satellite imagery could provide a cost-effective mechanism for correcting for land transformation and degradation, but this would require field calibration of the effects of different levels of observed degradation on standing basal area. Up to this point, imagery analysis has been conducted only on limited areas and with limited or no ground verification.

The results indicate that at a national level, there is a potential for sustainable fuel consumption, assuming that most of the savanna areas are maintained in a seminatural state. This would mean zero net $\mathrm{CO}_{2}$ emissions, given uniform usage of the resource. However, it must also be noted that fuelwood consumption is not uniform over the savanna regions; high nonsustainable consumption is concentrated around areas with high population densities. Within South Africa and many other African states, betterment programs (resettlement programs forcing communities into villages) have resulted in highdensity nuclear settlements. These settlements are often located close to agricultural fields that are totally cleared of bush, which reduces the area available for fuelwood production. 
Table I indicates that in some of the ex-Bantustan areas there is potential for sustainable fuel production, but this conclusion does not take into account the fact that land degradation and transformation have greatly reduced the area available for production of fuelwood. In other ex-Bantustans, consumption exceeds maximum potential production. Fuelwood consumption is probably at unsustainable levels at localized sites in all the ex-Bantustans, although there is potentially a surplus in a few instances. Harvesting fuelwood for sale in nonsavanna regions and periurban and urban areas may further increase the level of consumption in some regions.

Although South Africa has almost no charcoal trade, in nations such as Tanzania, Malawi, Zambia, and Mozambique charcoal trade is very active. Once areas of woodland have been cleared for charcoal production, they are often converted to agricultural use, and no tree regeneration can occur.

Fuelwood consumption patterns change as fuelwood becomes scarcer. Traditional resource management practices on communal land limit fuelwood collection to dead wood; and in such cases, fuelwood consumption is sustainable. However, increased population pressure and the conversion of land from woodlands to agriculture or other uses increase the pressure on the remaining woodlands. This can lead to the harvesting of live wood to meet the shortfall in fuelwood. If this occurs, there will be a net emission of $\mathrm{CO}_{2}$ from the region. However, as fuelwood becomes scarce, its value increases, which often results in a switch to alternative energy sources, such as paraffin. The system may then stabilize at a lower level of sustainable wood consumption, or the wood resources may become locally depleted.

\subsection{Precautions when Interpreting the Data}

Because this is the first time that a production (versus a standing crop) estimate has been made for savannas in South Africa, there are no data to verify the prediction. It should, therefore, be regarded as tentative.

Each step in the modeling process relies on regression equations. The data on which these models are based are, in most instances, limited to fairly small data sets. Where possible, these have been validated against independently collected data.

The models should give a reasonable prediction of total woody biomass production of savannas at the national level, but estimates for limited areas or specific points on the ground may differ substantially from the values predicted in the model. The results should not be expressed at a scale smaller than the magisterial district.

\section{Conclusions}

The methodology described in this paper provides an efficient way to predict potential fuelwood production at a regional, national, or continental level. At a regional level predictions about fuelwood production can be combined with fuelwood consumption data to allow for calculation of unsustainable consumption. It must be recognized, however, that consumption patterns are spatially heterogeneous and that localized overconsumption 
is not compensated for by underconsumption in other areas. Although there is potential for sustainable consumption in South Africa at a national level, localized consumption is not operating in a sustainable fashion, and this is leading to net $\mathrm{CO}_{2}$ emission and degradation of the savanna resource.

\section{References}

Acocks, J.P.H.: 1988, Veld types of south Africa. Memoirs of the Botanical Survey of South Africa 57, 146 pages.

Allen, J.C.: 1985, Wood energy and preservation of woodlands in semi-arid developing countries. The case of Dodoma region, Tanzania, Journal of Development Economics 19, 59-84.

Anderson, D.: 1986, Declining tree stocks in African Countries, World Development 14, 853-863.

Bajracharya, D.: 1983, Fuel, food or forest? Dilemmas in a Nepali village, World Development 11, 10571074.

Best, M.: 1979, The scarcity of domestic energy: a study of three villages, SALDRU working paper no. 27, University of Cape Town.

Dayton, B.R.: 1978, Standing crops of dominant Combretum species at three browsing levels in the Kruger National Park, Koedoe 21, 67-76.

Eberhard, A.A.: 1986, Energy Consumption Patterns in Underdeveloped Areas in South Africa, Energy Research Institute Report No 94, University of Cape Town, South Africa.

Eberhard, A.A. and Dickson, B.J: 1987, Energy Consumption Patterns and Alternative Energy Supply Strategies for Underdeveloped Areas of Bophuthatswana, Energy Research Institute, University of Cape Town, South Africa.

Ellery, W.N.: 1992, Classification of the Vegetation of the South African Grassland Biome, PhD thesis, University of the Witwatersrand, Johannesburg, South Africa, 211 pages.

Endean, F.: 1967, The productivity of miombo woodland in Zambia, Forest Research Bulletin 14, Lusaka, Zambia: Government Printer.

Frost, P.G.H: Undated, The ecology of miombo woodlands. Unpublished manuscript in preparation. Department of Biological Sciences, University of Zimbabwe, Harare, Zimbabwe.

Guy, P.R.: 1981, The estimation of the aboveground biomass of the trees and shrubs in the Sengwa Wildlife Research Area, Zimoabwe, Southern African Journal of Wildlife Research 11, 135-142.

Gander, M.: 1992, Domestic Energy Used by Farmworkers Living on Commercial Farmland in Natal and Transvaal, Report to the Department of Mineral and Energy Affairs, South Africa.

Gander, M.: 1994, Afforestation and Woodland Management in South Africa. EDRC paper no 9, University of Cape Town, South Africa.

Lubke, R.A. and Thatcher, F.M.: 1983, Short term change in the Burkea savanna, South African Journal of Botany 2, 85-97

Kanetkar, R.S and Kaul. O.N.: 1994, The energy dimension of Indian Forests. Workshop of the joint research project on the forests in South- and North-transition from deforestation to sustainable forest policies in redressing global warming, Joensuu, Finland, 17 pages.

Kaul, O.N.: 1993, Forest biomass burning in India, in The Climate Change Agenda: An Indian Perspective, 65-90, Tata Energy Research Institute, New Delhi.

Malaisse, F., Freson, R., Geoffinet, G., and Maalaisse-Mousset, M.: 1975, Litterfall and litter breakdown in miombo, in Golley, F.B. and Medina, E. (eds.), Tropical Ecological Systems: Trends in Terrestrial and Aquatic Research, Berlin: Springer-Verlag, 137-55.

Malaisse, F. and Strand, M.A.: 1973, A preliminary miombo forest seasonal model, in Kern, L. (ed.), Modeling Forest Ecosystems, I.B.P., Woodland Workshop, Oak Ridge, USA, 29-295.

Moore, A.W., Russel, J.S., and Coaldrake, J.E.: 1967, Dry matter and nutrient content of a subtropical semiarid forest of Acacia harpophylla F. Muell. (Bigalow). Australian Journal of Botany 15, 11-24.

Rutherford, M.C. and Kelly, R.D.: 1978, Woody plant basal area and stem increment in Burke africanaOchna pulchra woodland, South African Journal of Science 74, 307-308.

Rutherford, M.C.: 1982, Woody Plant Biomass Distribution in Burkea africana Savannas, in Huntley, B.J. and Walker, B.H. (eds.), Ecology of Tropical Savannas. Ecological Studies 42, Berlin: Springer-Verlag.

Rutherford, M.C. and Westfall, R.H.: 1986, Biomes of southern African objective categorization, Memoirs of the Botanical Survey of South Africa, 54. 
Rutherford, M.C.: 1984, Relative allocation and seasonal growth of woody plant components in a South African Savanna, Progress in Biometeorology 3, 45-63.

Shackelton, C.M.: 1994, Sustainable Veld Management and Its Role in Social Forestry and Energy Planning. Plant for Life Conference Proceedings, September 1994, Department of Mineral Affairs and Forestry, Pretoria, South Africa, 24 pages.

Scholes, R.J.: 1988, Response of Three Semi-Arid Savannas on Contrasting Soils to the Removal of the Woody Component, $\mathrm{PhD}$ Thesis, University of the Witwatersrand, Johannesburg, 297 pages.

Scholes, R.J.: 1990, The influence of soil fertility on the ecology of southern African dry savannas, Journal of Biogeography 17, 415-419.

Scholes, R.J.: 1993, Nutrient Cycling in Semi-Arid Grasslands and Savannas: Its Influence on Pattern, Productivity and Stability, Proceedings of the XVII International Grassland Congress, 1993.

Scholes, R.J and Walker, B.H.: 1993, An African savanna: synthesis of the Nylsvley study, Cambridge: Cambridge University Press.

UNEP, OECD, IEA, IPCC (United Nations Environment Programme, Organisation for Economic Cooperation and Development, International Energy Agency, Intergovernmental Panel on Climate Change): 1995, IPCC Guidelines for National Greenhouse Gas Inventories, IPCC, Bracknell, 3 Volumes.

van Vegten, J.A.: 1984, Thornbush invasion in a savanna ecosystem in eastern Botswana, Vegetation 56, 3-7. 